\title{
Biochar Improves Root Growth of Sapium sebiferum (L.) Roxb. Container Seedlings
}

\author{
Hong Chen $(\mathbb{D}$, Chen Chen and Fangyuan Yu * \\ Collaborative Innovation Centre of Sustainable Forestry in Southern China, College of Forest Science, \\ Nanjing Forestry University (NJFU), 159 Longpan Road, Nanjing 210037, China; hongchen@njfu.edu.cn (H.C.); \\ cc0212@njfu.edu.cn (C.C.) \\ * Correspondence: fyyu@njfu.edu.cn
}

Citation: Chen, H.; Chen, C.; Yu, F. Biochar Improves Root Growth of Sapium sebiferum (L.) Roxb. Container Seedlings. Agronomy 2021, 11, 1242. https://doi.org/10.3390/ agronomy11061242

Academic Editor: Sara Di Lonardo

Received: 31 May 2021

Accepted: 16 June 2021

Published: 19 June 2021

Publisher's Note: MDPI stays neutral with regard to jurisdictional claims in published maps and institutional affiliations.

Copyright: (c) 2021 by the authors. Licensee MDPI, Basel, Switzerland. This article is an open access article distributed under the terms and conditions of the Creative Commons Attribution (CC BY) license (https:// creativecommons.org/licenses/by/ $4.0 /)$.

\begin{abstract}
Background: The faulty development of the root system is a major threat that affects the survival rate of container seedlings of Sapium sebiferum in the transplanting and reforestation processes. The current study was conducted to determine the impact of biochar on the root growth and development of S. sebiferum container seedlings. Methods: Varied concentrations (1\%, 3\%, and $5 \%$ ) of straw and bamboo biochar were applied in six groups, whereas the control group (CK) was only treated with matrix. Results: The treatment with $3 \%$ straw biochar $(\mathrm{C} 2)$ proved to be the most effective soil conditioner for cultivating S. sebiferum seedlings. Moreover, C2 increased seedling height $(58.92 \%)$; ground diameter $(33.86 \%$, biomass of the over-ground part $(12.73 \mathrm{~g})$, the underground part $(7.48 \mathrm{~g})$, and the fibrous part $(0.076 \mathrm{~g})$ compared to the CK (control). Conclusions: Biochar not only improved the root morphology by developing primary lateral roots, but it also accelerated the assimilation of $\mathrm{N}$ from the matrix to indirectly facilitate stem growth through enhancing NR activity. The change in root growth strategy contributed to the growth in S. sebiferum seedlings, thereby improving the survival rate during transplanting and reforestation.
\end{abstract}

Keywords: S. sebiferum; straw biochar; bamboo biochar; root system; nitrate reductase

\section{Introduction}

Sapium sebiferum (L.) Roxb. is commonly known as the Chinese tallow tree, belonging to the family Euphorbiaceae. It is a deciduous tree, native to semitropical regions of Southern and Central China. It was also introduced to Japan [1,2] (p. 93). S. sebiferum is an essentially economical tree due to the high oil content (up to 55\%) in its seeds. It follows the algae and oil palm and is ranked the third highest biodiesel-producing crop in the world. It has been regarded as one of China's four major woody oil plants (tallow, tea, tung oil, and walnuts) [3-5] (pp. 1-12). The waxy coating of its seeds can be the raw material for soap. Moreover, S. sebiferum is a colorful foliage tree species with high ornamental value. Thus, it can be planted in gardens and on roadsides. Furthermore, it has medical uses for preventing snail fever [6]. In general, S. sebiferum is a multi-functional plant. The mass planting of $S$. sebiferum is the result of its practical value. Hence, the container seedlings of this important species have become prevalent for transplanting and reforestation on a large scale. However, the survival rate of seedlings is negatively affected by insufficiently developed root systems [7]. To resolve this problem, our experiment aims to enhance its root growth with biochar based on previous studies finding that biochar can amend root growth $[8,9]$.

Currently, there is a rising interest in a charcoal product termed biochar as a potential soil conditioner to improve soil quality and carbon sequestration to mitigate climate change $[10,11]$. Biochar is generated by the pyrolysis of biomass at temperatures between 300 and $1000{ }^{\circ} \mathrm{C}$ in oxygen-limited conditions [12,13], which is initially derived from chernozem in the Amazon River [14]. Biochar does not solely assist in retaining carbon, but also has impacts on soil physical property and soil biota. Independently, mixed biochar 
can reduce soil bulk density and improve whole soil porosity due to the porous structure of biochar [15]. The studies conducted by Burrell et al. [16] indicated that biochar can amend soil physical structures by improving soil aggregate stability and plant available water, especially in coarse-textured soil. In addition, biochar can act as a slow-release fertilizer, enhancing soil fertility of acidic soils in the long-term [16]. With respect to soil nitrogen, biochar can increase biological nitrogen fixation, accelerate organic nitrogen mineralization, and prevent $\mathrm{NH}_{3}$ loss from soils $[17,18]$. Biochar has direct impacts on the soil nitrogen cycle $[19,20]$ through two mechanisms: improving the $\mathrm{pH}$ of soils and strengthening chemical signaling between the host and symbiont [17,21,22]. Moreover, previous studies concluded that biochar can affect soil microbial communities and enzymes activities [23-25].

Referring to previous studies, it was hypothesized that biochar can improve the root growth of $S$. sebiferum container seedlings by improving soil physical property, providing more nutrients, and activating microbes or enzymes [26]. Li et al. [27] reported that a $1.5 \%$ biochar addition can change root morphology and improve $\mathrm{N}$ absorption capacity of Phragmites australis. Compared to the study by Li et al. [27], we selected two types of biochar at three separate concentration levels. Our experiment not only aimed to prove the hypothesis above, but also to assess the superior type of biochar and proper concentration for enhancing root growth of $S$. sebiferum. In general, we explored the proper and scientific cultivation of $S$. sebiferum container seedlings, especially in its root system. Hence, the root system can become stronger and more resistant to stress, thereby improving the survival rate of transplanting and reforestation.

\section{Materials and Methods}

\subsection{Experimental Materials}

The container seedlings of S. sebiferum for the test were obtained from Shanghai Forest Vegetation Germplasm Resource Base $\left(121^{\circ} 20^{\prime} \mathrm{E}, 31^{\circ} 23^{\prime} \mathrm{N}\right)$. In early April 2018, the seeds of S. sebiferum collected in Xinyi, Jiangsu, in mid-November 2017 were processed with $1 \% \mathrm{NaOH}$ [28] and sowed in plug trays after cleaning. On 21 June 2018, the seedlings of appropriate $10 \mathrm{~cm}$ height were transplanted to a biochar matrix with different contents in a non-woven container.

\subsection{Pot Experiment}

Two types of biochar (straw and bamboo) were set up at three levels $(1 \%, 3 \%$, and $5 \%$ ) for each type, including six treatment groups $\left(C_{1}, C_{2}, C_{3}, C_{4}, C_{5}\right.$, and $\left.C_{6}\right)$. The control group $(\mathrm{CK})$ contained the test substrate without biochar, while the experimental groups were mixed with various contents of biochar, which were the proportion of matrix mass (Table 1). Three replicates were evenly set for each treatment with 30 seedlings. Seedlings were cultivated in the same container and substrate.

Table 1. The design of biochar treatments.

\begin{tabular}{ccc}
\hline Treatments & Straw Biochar Content & Bamboo Biochar Content \\
\hline$C_{K}$ & 0 & 0 \\
$C_{1}$ & $1 \%$ & 0 \\
$C_{2}$ & $3 \%$ & 0 \\
$C_{3}$ & $5 \%$ & 0 \\
$C_{4}$ & 0 & $3 \%$ \\
$C_{5}$ & 0 & $3 \%$ \\
$C_{6}$ & 0 & $5 \%$ \\
\hline
\end{tabular}

\subsection{Plant Samplings and Analysis}

\subsubsection{Seedling Height and Ground Diameter}

Before harvest, 15 seedlings of $S$. sebiferum were randomly selected for each repetition to determine the seedling height and ground diameter with a tape measure $(0.1 \mathrm{~cm}$ 
accuracy) and a Vernier caliper (0.01 mm accuracy), respectively. Furthermore, the heightdiameter ratio was calculated.

\subsubsection{Root System Indexes}

Prior to the end of the trial, $5 \mathrm{~S}$. sebiferum seedlings were randomly selected for each treatment and repetition (15 plants per treatment). After cleaning the root system with water, a transmission image was obtained under an EPSON scanner (Seiko Epson Corp., Gen, Japan), and the root image was analyzed with WinRHIZO PRO 2007 (Gen, Japan) [29]. Root system indexes include total root length, root surface area, root volume, average root diameter, and lateral root length, with a variety of diameters [30]. The number of primary lateral roots with a diameter greater than $1 \mathrm{~mm}$ (the roots on the main root were not included) was determined by direct observation.

\subsubsection{Biomass}

The 15 seedlings of S. sebiferum were divided into the aboveground part and underground parts (main lateral roots and fibrous roots) with root scanning. These seedlings were placed into an oven with envelopes. The oven temperature was initially at $105^{\circ} \mathrm{C}$ for $30 \mathrm{~min}$ to kill them and was subsequently adjusted to $70{ }^{\circ} \mathrm{C}$ to dry them to a constant weight. Eventually, an electronic balance with an accuracy of $0.001 \mathrm{~g}$ was utilized to measure the dry weight of each part separately.

\subsubsection{Non-Structure Carbohydrate}

The $0.2 \mathrm{~g}$ of fresh root samplings was separately collected to determine soluble sugar content and starch content via colorimetric analysis [31].

\subsubsection{Nitrate Reductase}

Nitrate reductase (NR) is a key enzyme in plant nitrogen metabolism, which is correlated with plant absorption and the use of nitrogen fertilizer [32]. The experiment determined NR in vitro [33].

\subsubsection{Nitrogen and Carbon Content}

Samples for determination of nitrogen and carbon content were collected every 30 days. Samplings were taken a total of five times, starting at the beginning of the test in June 2018 and ending in late November.

Nitrogen and carbon content of stem and root samples were determined when dried via the method by Sorrenti et al. [34] and external heating of potassium dichromate methods (referring to GB7857-1987), respectively.

\subsection{Statistical Analysis}

Excel 2016 (Microsoft, Redmond, WA, USA) and Origin 2018 (OriginLab, Northampton, MA, USA) were adopted for processing data and figures. SPSS 23.0 (IBM, Armonk, NY, USA) was used for analysis of variance (ANOVA) and Duncan's multiple range test. $p$ values less than 0.05 were considered to indicate significance between groups.

\section{Results}

\subsection{Seedling Height, Ground Diameter, and Height-Diameter Ratio}

The discrepancies in seedling height, ground diameter, and the height-diameter ratio between treatment groups and CK were significant $(p<0.05)$, indicating that biochar had a positive impact on the seedling morphological indicators of S. sebiferum above. Compared to other treatments, $C_{2}$ significantly enhanced growth of both seedling height and ground diameter. This result illustrated that $S$. sebiferum treated with 3\% straw biochar performed the best in terms of seedling growth. Moreover, the height-diameter ratios of all treatments were elevated compared to $\mathrm{CK}$, on account of biochar having a stronger promotion effect on seedling height growth compared to ground diameter growth (Table 2). 
Table 2. The seedling height, ground diameter, and height-diameter ratio of S. sebiferum container seedlings in different biochar treatments.

\begin{tabular}{cccc}
\hline Treatment & Seedling Height $(\mathbf{c m})$ & Ground Diameter $(\mathbf{m m})$ & Height-Diameter Ratio \\
\hline $\mathrm{CK}$ & $63.60 \pm 4.68 \mathrm{c}$ & $7.56 \pm 0.39 \mathrm{c}$ & $83.1 \pm 3.20 \mathrm{c}$ \\
$\mathrm{C}_{1}$ & $100.67 \pm 3.76 \mathrm{a}$ & $9.99 \pm 0.37 \mathrm{ab}$ & $101.7 \pm 3.83 \mathrm{ab}$ \\
$\mathrm{C}_{2}$ & $101.07 \pm 3.92 \mathrm{a}$ & $10.12 \pm 0.34 \mathrm{a}$ & $100.2 \pm 3.13 \mathrm{~b}$ \\
$\mathrm{C}_{3}$ & $89.47 \pm 2.71 \mathrm{~b}$ & $8.97 \pm 0.26 \mathrm{~b}$ & $100.1 \pm 2.39 \mathrm{~b}$ \\
$\mathrm{C}_{4}$ & $101.27 \pm 1.85 \mathrm{a}$ & $9.22 \pm 0.23 \mathrm{bc}$ & $110.5 \pm 2.73 \mathrm{a}$ \\
$\mathrm{C}_{5}$ & $91.40 \pm 2.11 \mathrm{ab}$ & $8.75 \pm 0.26 \mathrm{~b}$ & $105.2 \pm 2.86 \mathrm{ab}$ \\
$\mathrm{C}_{6}$ & $96.13 \pm 2.28 \mathrm{ab}$ & $8.84 \pm 0.24 \mathrm{~b}$ & $109.2 \pm 2.18 \mathrm{ab}$ \\
\hline
\end{tabular}

Lowercase letters represent significance at the 0.05 level and the same letter indicates no significant difference in full text.

\subsection{Biomass}

Table 3 displays the biomass of the aboveground part, the underground part, and fibrous roots treated with two biochar types at three content levels. Obvious differences occurred between treatment groups and CK $(p<0.05)$. The $C_{2}$ treatments were affected more positively on the aboveground biomass and underground biomass, showing that treatments containing 3\% straw biochar produced the strongest acceleration of growth of the aboveground and underground biomass. Despite biochar facilitating both the biomass of aboveground and underground parts, the facilitation of the former was superior to that of the latter. Thereby, the root-stem ratios of all treatment groups were inferior to the control group. Nonetheless, slight discrepancies in the root-stem ratio appeared among all treatments.

Table 3. The biomass of various parts of S. sebiferum container seedlings in different biochar treatments.

\begin{tabular}{ccccc}
\hline Treatment & $\begin{array}{c}\text { Over-Ground } \\
\text { Part (g) }\end{array}$ & $\begin{array}{c}\text { Underground } \\
\text { Part (g) }\end{array}$ & Fibrous Roots (g) & Root-Stem Ratio \\
\hline $\mathrm{CK}$ & $3.77 \pm 0.78 \mathrm{~d}$ & $3.59 \pm 0.65 \mathrm{c}$ & $0.036 \pm 0.009 \mathrm{c}$ & $1.05 \pm 0.09 \mathrm{a}$ \\
$\mathrm{C}_{1}$ & $15.08 \pm 1.83 \mathrm{ab}$ & $9.88 \pm 1.16 \mathrm{a}$ & $0.189 \pm 0.032 \mathrm{ab}$ & $0.66 \pm 0.03 \mathrm{~b}$ \\
$\mathrm{C}_{2}$ & $16.50 \pm 2.94 \mathrm{a}$ & $11.07 \pm 1.69 \mathrm{a}$ & $0.112 \pm 0.022 \mathrm{~b}$ & $0.70 \pm 0.05 \mathrm{~b}$ \\
$\mathrm{C}_{3}$ & $9.29 \pm 0.80 \mathrm{c}$ & $6.22 \pm 0.74 \mathrm{bc}$ & $0.182 \pm 0.040 \mathrm{ab}$ & $0.66 \pm 0.04 \mathrm{~b}$ \\
$\mathrm{C}_{4}$ & $10.67 \pm 0.97 \mathrm{bc}$ & $6.46 \pm 0.77 \mathrm{bc}$ & $0.193 \pm 0.063 \mathrm{ab}$ & $0.60 \pm 0.05 \mathrm{~b}$ \\
$\mathrm{C}_{5}$ & $9.35 \pm 0.75 \mathrm{c}$ & $6.37 \pm 0.51 \mathrm{bc}$ & $0.122 \pm 0.103 \mathrm{a}$ & $0.70 \pm 0.06 \mathrm{~b}$ \\
$\mathrm{C}_{6}$ & $11.19 \pm 1.31 \mathrm{bc}$ & $8.20 \pm 0.77 \mathrm{ab}$ & $0.131 \pm 0.015 \mathrm{~b}$ & $0.76 \pm 0.07 \mathrm{~b}$ \\
\hline
\end{tabular}

Lowercase letters represent significance at 0.05 level and the same letter indicates no significant difference in full text.

\subsection{Root System}

The root morphological indexes of S. sebiferum container seedlings under a variety of biochar treatments, as displayed in Table 4, include primary lateral root number, total root length, root surface area, and root volume. The results indicated that all biochar contents in the trial can promote these root morphological indicators, and that significant discrepancies between treatments and CK occurred $(p<0.05)$. The results presented that straw charcoal better-facilitated the generation of fibrous roots than bamboo charcoal, especially for $3 \%$ straw charcoal due to the increase in porosity of the matrix in retaining moisture [34]. In addition, the matrix mixing 5\% straw biochar with $3 \%$ straw biochar contributed to the largest root volume. 
Table 4. The root morphological indexes of S. sebiferum container seedlings in different biochar treatments.

\begin{tabular}{|c|c|c|c|c|}
\hline Treatment & $\begin{array}{l}\text { Primary Lateral } \\
\text { Root Number }\end{array}$ & $\begin{array}{l}\text { Total Root Length } \\
(\mathrm{cm})\end{array}$ & $\begin{array}{l}\text { Root Surface } \\
\text { Area }\left(\mathrm{cm}^{2}\right)\end{array}$ & $\begin{array}{l}\text { Root Volume } \\
\left(\mathrm{cm}^{3}\right)\end{array}$ \\
\hline CK & $2.00 \pm 0.41 \mathrm{c}$ & $145.7 \pm 20.10 \mathrm{~d}$ & $122.3 \pm 23.07 \mathrm{~b}$ & $2.33 \pm 0.95 b$ \\
\hline $\mathrm{C}_{1}$ & $5.33 \pm 0.55 \mathrm{a}$ & $365.3 \pm 33.55 b c$ & $194.2 \pm 12.20 \mathrm{~b}$ & $7.84 \pm 0.53 c$ \\
\hline $\mathrm{C}_{2}$ & $5.56 \pm 0.78 \mathrm{a}$ & $463.6 \pm 40.63 \mathrm{ab}$ & $227.8 \pm 15.94 \mathrm{ab}$ & $11.39 \pm 1.01 \mathrm{bc}$ \\
\hline $\mathrm{C}_{3}$ & $5.22 \pm 0.68 \mathrm{a}$ & $455.5 \pm 21.74 \mathrm{ab}$ & $241.1 \pm 16.12 \mathrm{ab}$ & $11.55 \pm 1.24 \mathrm{abc}$ \\
\hline $\mathrm{C}_{4}$ & $3.00 \pm 0.33 \mathrm{bc}$ & $345.1 \pm 40.54 c$ & $284.7 \pm 26.06 \mathrm{a}$ & $10.43 \pm 2.57 \mathrm{a}$ \\
\hline $\mathrm{C}_{5}$ & $4.33 \pm 0.94 \mathrm{ab}$ & $391.9 \pm 24.83 b c$ & $243.3 \pm 14.30 \mathrm{ab}$ & $10.14 \pm 2.03 \mathrm{abc}$ \\
\hline $\mathrm{C}_{6}$ & $4.67 \pm 0.58 \mathrm{ab}$ & $420.9 \pm 50.66 \mathrm{a}$ & $239.0 \pm 16.26 \mathrm{ab}$ & $10.77 \pm 6.16 \mathrm{ab}$ \\
\hline
\end{tabular}

Lowercase letters represent significance at 0.05 level and the same letter indicates no significant difference in full text.

\subsection{The Concentration of Non-Structure Carbohydrate and Nitrate Reductase Activity}

The concentration of non-structure carbohydrate and nitrate reductase activity in the roots of S. sebiferum container seedlings treated with biochar are shown in Table 5. The discrepancies of soluble sugar and starch concentration among the treatments and control were significant $(p<0.05)$. The results indicated that biochar can significantly reduce the content of soluble sugar and starch in the root system. The pattern of response of plants for soluble sugar concentration was $\mathrm{CK}>\mathrm{C}_{1}, \mathrm{C}_{5}, \mathrm{C}_{4}, \mathrm{C}_{3}, \mathrm{C}_{6}>\mathrm{C}_{2}$, while the starch concentration followed the order $\mathrm{CK}>\mathrm{C}_{1}, \mathrm{C}_{6}, \mathrm{C}_{5}, \mathrm{C}_{3}, \mathrm{C}_{2}>\mathrm{C}_{4}$. Compared to the other concentrations, $3 \%$ straw biochar proved to be the non-structure carbohydrate most consumed by seedlings in producing energy for photosynthesis, ultimately enhancing plant growth and development.

Table 5. The concentration of non-structure carbohydrate and nitrate reductase activity in the roots of $S$. sebiferum container seedlings with different biochar treatments.

\begin{tabular}{cccc}
\hline Treatment & $\begin{array}{c}\text { Soluble Sugar } \\
(\mathbf{m g} / \mathbf{g} \text { FW })\end{array}$ & $\begin{array}{c}\text { Starch } \\
(\mathbf{m g} / \mathbf{g} \text { FW })\end{array}$ & $\begin{array}{c}\text { NR Activity } \\
\left(\boldsymbol{\mu} \mathbf{g} \cdot \mathbf{g}^{-\mathbf{1}} \cdot \mathbf{h}^{-\mathbf{1}}\right)\end{array}$ \\
\hline $\mathrm{CK}$ & $31.06 \pm 1.39 \mathrm{a}$ & $92.10 \pm 12.27 \mathrm{a}$ & $9.37 \pm 0.68 \mathrm{~b}$ \\
$\mathrm{C}_{1}$ & $26.26 \pm 3.47 \mathrm{ab}$ & $67.22 \pm 25.45 \mathrm{ab}$ & $4.25 \pm 0.65 \mathrm{c}$ \\
$\mathrm{C}_{2}$ & $21.15 \pm 1.67 \mathrm{~b}$ & $52.32 \pm 7.61 \mathrm{ab}$ & $32.50 \pm 1.12 \mathrm{a}$ \\
$\mathrm{C}_{3}$ & $23.56 \pm 0.96 \mathrm{ab}$ & $56.83 \pm 6.59 \mathrm{ab}$ & $11.61 \pm 2.24 \mathrm{~b}$ \\
$\mathrm{C}_{4}$ & $23.68 \pm 5.22 \mathrm{ab}$ & $41.80 \pm 8.72 \mathrm{~b}$ & $3.77 \pm 0.15 \mathrm{c}$ \\
$\mathrm{C}_{5}$ & $24.41 \pm 1.67 \mathrm{ab}$ & $59.82 \pm 5.54 \mathrm{ab}$ & $9.92 \pm 1.86 \mathrm{~b}$ \\
$\mathrm{C}_{6}$ & $22.61 \pm 1.68 \mathrm{ab}$ & $63.50 \pm 7.43 \mathrm{ab}$ & $9.12 \pm 0.54 \mathrm{~b}$ \\
\hline
\end{tabular}

Lowercase letters represent significance at 0.05 level and the same letter indicates no significant difference in full text.

It is evident from Table 5 that the NR activity of the roots of S. sebiferum increased with the age of the plant and further increased with the application of straw charcoal. Maximum NR activity was noted in the plants treated with $3 \%\left(C_{2}\right)$ straw charcoal. The pattern of response of plants with straw charcoal was $\mathrm{C}_{2}>\mathrm{C}_{3}, \mathrm{C}_{5}, \mathrm{CK}, \mathrm{C}_{6}>\mathrm{C}_{1}, \mathrm{C}_{4}$. Moreover, $\mathrm{C}_{2}$ had a striking discrepancy with other treatments $(p<0.05)$. Out of the two charcoals used, the response toward straw charcoal was more pronounced compared to bamboo charcoal.

\subsection{Nitrogen Concentration, Carbon Concentration, and N/C Ratio in Roots}

The nitrogen concentration in the roots of S. sebiferum container seedlings treated with various biochars in different periods (from July to November) is indicated in Figure 1. In general, biochar significantly increased $\mathrm{N}$ concentration in the early stage (July), and the matrix mixed with straw charcoal led to more $\mathrm{N}$ accumulation than bamboo charcoal. It was reported earlier that loose and porous straw charcoal increased the interstices of the matrix, benefiting the maintenance of moisture and the growth in the root system [35]. Subsequently, $\mathrm{N}$ concentration decreased rapidly in August, followed by the gentle uptrend or downtrend in the latter stages. Nevertheless, $\mathrm{N}$ concentration in CK kept the gentle 
uptrend without reduction. The peak value of $\mathrm{N}$ in $\mathrm{CK}$ did not exceed the $\mathrm{N}$ concentration of treatments in July due to the slow growth of $\mathrm{CK}$, which did not reach the declining stage.

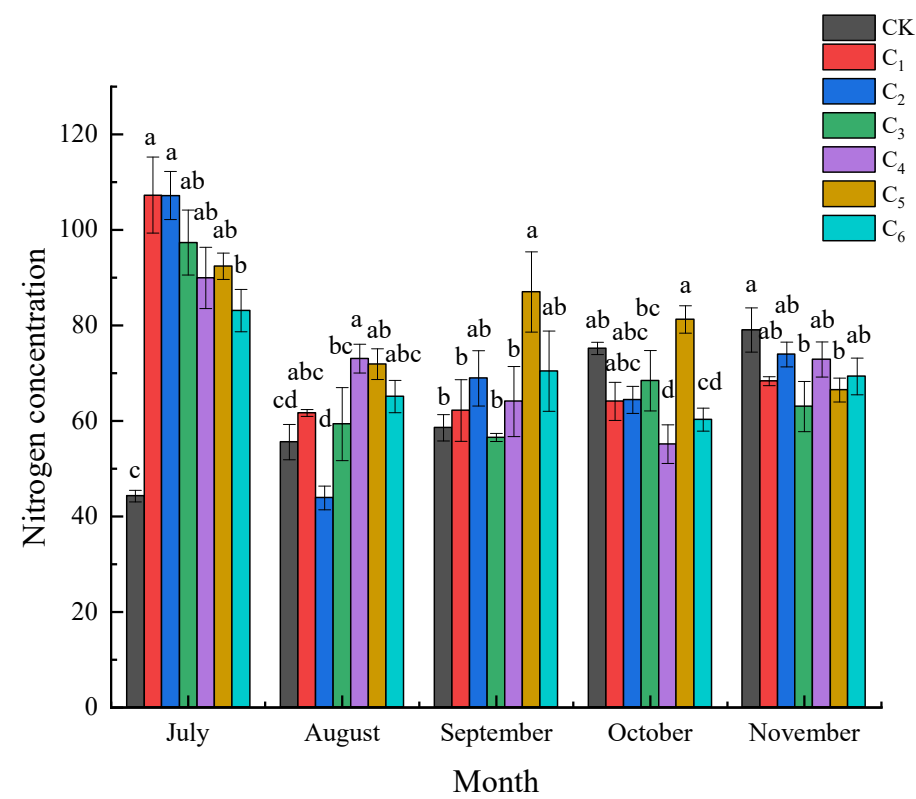

Figure 1. The nitrogen concentration in the roots of S. sebiferum container seedlings with different biochar treatments. Lowercase letters represent significance at 0.05 level and the same letter indicates no significant difference in full text.

The entire carbon concentration of all treatments was retained at a similar level. In November, the carbon concentration of $C_{3}$ and $C_{4}$ had noticeable discrepancies compared to other experimental groups and CK. No significant difference occurred in the first four months (Figure 2), illustrating that biochar had slight impacts on the carbon concentration in the roots of S. sebiferum. The trends in the carbon-nitrogen ratio in roots agree with the trends in the $\mathrm{N}$ concentration in roots (Figure 3).

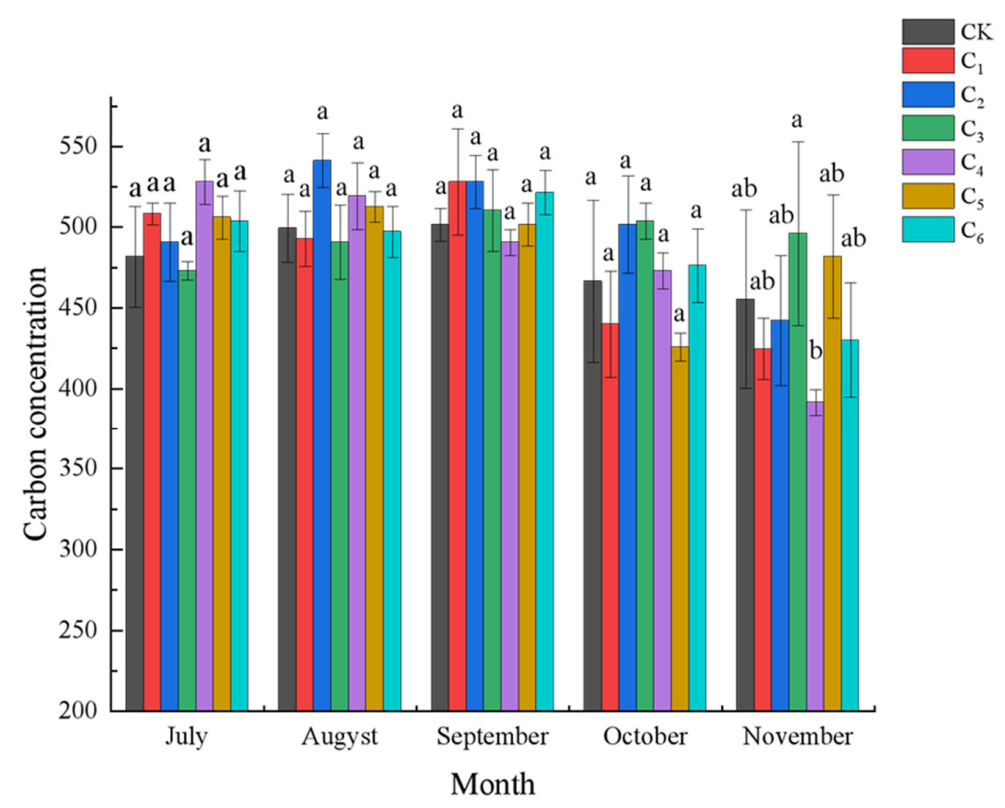

Figure 2. The carbon concentration in the roots of S. sebiferum container seedlings with different biochar treatments. Lowercase letters represent significance at 0.05 level and the same letter indicates no significant difference in full text. 


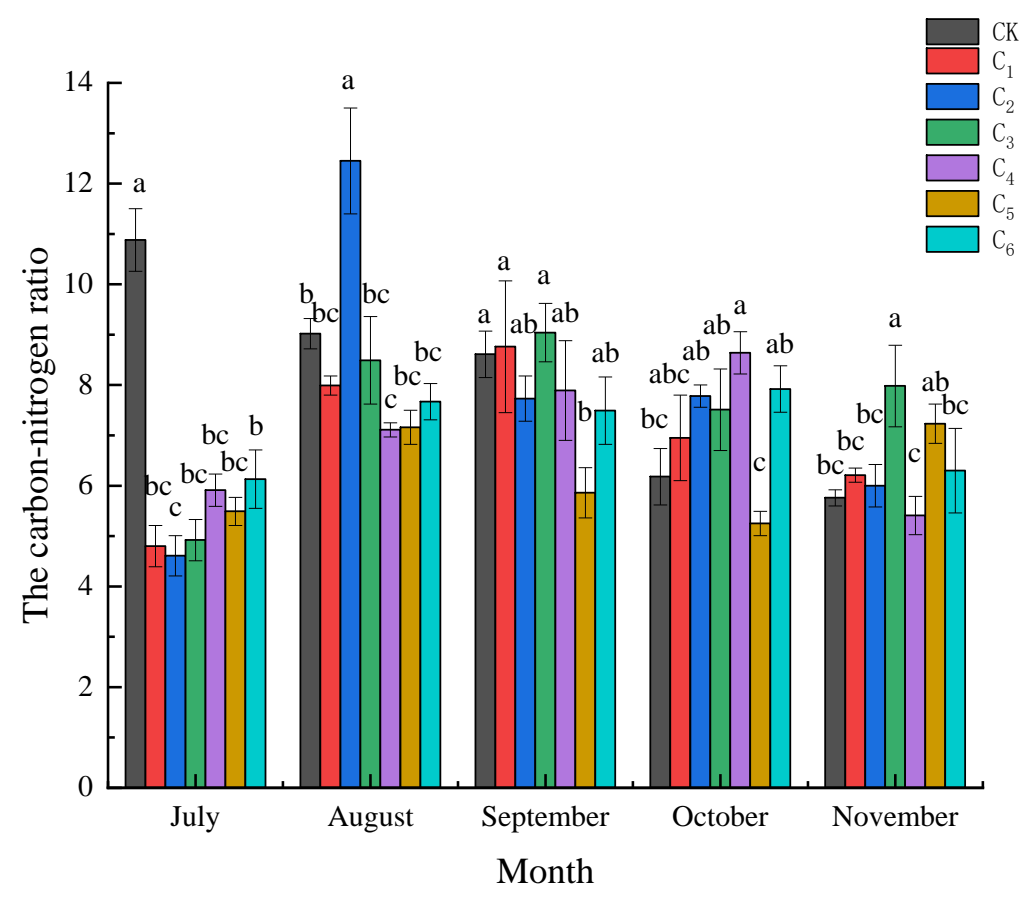

Figure 3. The carbon-nitrogen ratio in the roots of S. sebiferum container seedlings with different biochar treatments. Lowercase letters represent significance at 0.05 level and the same letter indicates no significant difference in full text.

\section{Discussion}

The experiment aimed at testing the impacts of two biochar types on the morphological and physiological indicators of the root system of S. sebiferum container seedlings. The results indicated that biochar can improve seedling height, ground diameter, biomass, primary lateral roots, total root length, root surface area, and root volume of the model plant. These findings are consistent with a meta-analysis of the biochar effects on root traits $[9,36,37]$. Among the different treatments of biochar, $C_{2}(3 \%)$ proved to be the best for the development of seedlings.

Biochar can improve the physical characteristics of the soil matrix, including porosity and aeration. In general, the porosity of biochar can decrease the total bulk density of soil, thereby enlarging the growing habitat for the underground parts of seedlings. Compared to bamboo charcoal, straw charcoal is a finer biochar in nature [38], offering more space for the development of the primary lateral roots (Table 4). In addition, biochar contains a larger proportion of aromatic $C$, especially for fused aromatic $C$ structures [14]. According to the above characteristics, biochar has excellent water absorption and permeability properties, owing to its low bulk density and large surface area [39]. Straw biochar can preserve more water and nutrients over bamboo biochar [40]. Thus, the roots are inclined to horizontally obtain nutrients and moisture in shallow soils via adding lateral roots [41].

Biochar application increases the availability of nutrients with potassium, phosphorus, and zinc [42]. The leaning alkalinity of biochar can adjust the soil $\mathrm{pH}$ to a particularly ameliorate acidic soil [25]. Furthermore, $\mathrm{H}^{+}$and $\mathrm{Al}^{3+}$ are present in soils and react with the cations $\left(\mathrm{Ca}^{2+}, \mathrm{Mg}^{2+}\right.$, and $\mathrm{K}^{+}$, etc. $)$in biochar, reducing the soil base saturation. Chen et al. [43] reported that biochar can promote direct interspecies electron transfer (DIET). The application of biochar can increase total soil charge and cation exchange capacity (CEC) via its rich functional groups, thereby enhancing soil fertility $[44,45]$. As a mechanism of nutrient delivery to plants, biochar enhances soil fertility and soil quality by increasing the retention of soil moisture and nutrients, improving soil $\mathrm{pH}$ slightly, and stimulating the microbial activities of useful fungi $[46,47]$. Thus, biochar addition can accelerate the biomass accumulation and growth of seedling height and ground diameter (Tables 2 and 3). 
More importantly, plant growth and NR activity are positively related [48]. Biochar accelerates the assimilation of $\mathrm{N}$ from the matrix to indirectly facilitate stem growth through enhancing NR activity. According to Table 5,3\% straw biochar can markedly increase the NR activity of roots, thereby stimulating root system growth (Tables 4 and 5). Regarding the $\mathrm{N}$ content in roots, biochar amends soils with a slower release of nitrate to generate agronomic advantages [49]. It also enhances the mineralization of organic $\mathrm{N}$, the capability of which strengthens by adding more biochar [50,51]. Nielsen et al. [52] discovered that biochar application increased the soil $\mathrm{pH}$ by $0.2-0.3$ units, which accelerates the nitrification reduction reaction and reduces the $\mathrm{NO}^{3-}$ concentration in soils. Therefore, biochar provides more inorganic $\mathrm{N}$ for roots. Contrary to this, Laird et al. [51] reported that biochar enhances $\mathrm{N}$ leaching from the soil to restrict $\mathrm{N}$ assimilation of plants. Nevertheless, our experiment was implemented with container seedlings without the $\mathrm{N}$ leaching issue. Whereas biochar has fewer effects on carbon absorption by plants (Figure 2), several reports claim that biochar contributes to a larger carbon accumulation in soils [11]. Combined with the finding that biochar can promote root system growth and $\mathrm{N}$ absorption, the nutrients were absorbed into the stems during seedling growth, especially in the aboveground parts. An important finding in the present study is that the application of biochar enhanced seedling growth along with seedling height, ground diameter, and aboveground and underground biomass.

Additionally, both straw biochar and bamboo biochar can reduce soil contamination of heavy metals [38], benefiting the healthy development of plants. Compared to bamboo, straw biochar is finer, which can remove more soil contamination [38]. It may therefore be concluded from the above discussion and from the reports of Harel et al. [53] that a 3\% concentration of straw biochar relieves plants from external stress and is most beneficial to the cultivation of $S$. sebiferum container seedlings.

\section{Conclusions}

This study revealed that biochar is beneficial to the root growth of S. sebiferum seedlings and that $\mathrm{C}_{2}$ ( $3 \%$ straw biochar) is the most suitable soil conditioner for cultivating S. sebiferum seedlings. Biochar not only improved the root morphology by developing primary lateral roots, but also accelerated the assimilation of $\mathrm{N}$ from the matrix to indirectly facilitate stem growth by enhancing NR activity. The change in root growth strategy contributed to the growth in S. sebiferum seedlings, thereby improving the survival rate during transplanting and reforestation. Moreover, it was reported that biochar application increases soil $\mathrm{pH}$ due to the diffusion of minerals $(\mathrm{K}, \mathrm{Ca}$, and $\mathrm{Mg}$ ) from the biochar surface to soil. In addition, biochar has a rapid localized impact on soil $\mathrm{pH}$ with the distance from biochar $[54,55]$. Thus, the impact of biochar on plants is related to the original soil condition and the adaptability of plants to soil $\mathrm{pH}$. Combined with the growth habitat of certain plants, the methods of biochar application (e.g., location, concentration, etc.) should be studied in the future. Furthermore, different contents of biochar mixed with other fertilizers to form a composite matrix will be studied to explore its influence on the growth quality and survival rate of plants. Eventually, the optimal ratio of biochar and other fertilizers will be obtained to apply to production, providing impetus for the better promotion and application of biochar.

Author Contributions: Conceptualization, F.Y. and H.C.; methodology, F.Y. and H.C.; software, C.C. and H.C.; validation, F.Y.; investigation, C.C.; resources, F.Y.; writing-original draft preparation, H.C.; writing-review and editing, F.Y.; project administration, F.Y.; funding acquisition, F.Y. All authors have read and agreed to the published version of the manuscript.

Funding: The research was funded by National Natural Science Foundation of China, grant number 3197140894.

Institutional Review Board Statement: Not applicable.

Informed Consent Statement: Not applicable.

Data Availability Statement: Not applicable. 
Acknowledgments: The work was sponsored by National Natural Science Foundation of China (3197140894), Joint Research Project based on Cooperative Program for Bachelor of Science in Forestry by Nanjing Forestry University and University of British Columbia, and A Project Funded by the Priority Academic Program Development of Jiangsu Higher Education Institutions (PAPD).

Conflicts of Interest: The authors declare no conflict of interest.

\section{References}

1. Lin, J.; Harcombe, P.A.; Fulton, M.R.; Hall, R.W. Sapling growth and survivorship as affected by light and flooding in a river floodplain forest of southeast Texas. Oecologia 2004, 139, 399-407. [CrossRef]

2. Miller, J.H. Nonnative Invasive Plants of Southern Forests: A Field Guide for Identification and Control; General Technical Reports SRS-62; U.S. Department of Agriculture, Forest Service, Southern Research Station: Asheville, NC, USA, 2003 ; p. 93.

3. Potts, W.M.; Bolley, D.S. Analysis of the fruit of the Chinese tallow tree in Texas. J. Am. Oil Chem. Soc. 1946, 23, 316-318. [CrossRef]

4. Ruskin, H.A.K. Economic Analysis of Biofuels Production in Arid Regions. Ph.D. Thesis, The University of Arizona, Tucson, AZ, USA, 1983; pp. 1-12.

5. Liu, Y.; Xin, H.; Yan, Y. Physicochemical properties of Stillingia oil: Feasibility for biodiesel production by enzyme transesterification. Ind. Crop. Prod. 2009, 30, 431-436. [CrossRef]

6. Li, S.; Liu, J.; Tian, S.; Yin, T. Study on the causes of Sapium sebiferum seed dormancy and the methods for dormancy breaking. J. Nanjing For. Univ. 2011, 35, 1-4. (In Chinese)

7. Repáč, I.; Tučeková, A.; Sarvašová, I.; Vencurik, J. Survival and growth of outplanted seedlings of selected tree species on the High Tatra Mts. windthrow area after the first growing season. J. For. Sci. 2011, 57, 349-358. [CrossRef]

8. Sorrenti, G.; Muzzi, E.; Toselli, M. Root growth dynamic and plant performance of nectarine trees amended with biochar and compost. Sci. Hortic. 2019, 257, 108710. [CrossRef]

9. Xiu, L.; Zhang, W.; Wu, D.; Sun, Y.; Zhang, H.; Gu, W.; Wang, W.; Meng, J.; Chen, W. Biochar can improve biological nitrogen fixation by altering the root growth strategy of soybean in Albic soil. Sci. Total Environ. 2021, 773, 144564. [CrossRef]

10. Lehmann, J.; Gaunt, J.; Rondon, M. Bio-char sequestration in terrestrial ecosystems-A review. Mitig. Adapt. Strateg. Glob. Chang. 2006, 1, 403-427. [CrossRef]

11. Woolf, D.; Amonette, J.E.; Street-perrott, F.A.; Lehmann, J.; Joseph, S. Sustainable biochar to mitigate global climate change Dominic. Nat. Commun. 2010, 1, 56. [CrossRef]

12. Beesley, L.; Moreno-Jimenez, E.; Gomez-Eyles, J.L.; Harris, E.; Robinson, B.; Sizmur, T. A review of biochars' potential role in the remediation, revegetation and restoration of contaminated soils. Environ. Pollut. 2011, 159, 3269-3282. [CrossRef]

13. Chen, B.; Chen, Z. Sorption of naphthalene and 1-naphthol by biochars of orange peels with different pyrolytic temperatures. Chemosphere 2009, 76, 127-133. [CrossRef]

14. Lehmann, J. Bio-energy in the black. Front. Ecol. Environ. 2007, 5, 381-387. [CrossRef]

15. Weber, K.; Quicker, P. Properties of biochar. Fuel 2018, 217, 240-261. [CrossRef]

16. Burrell, L.D.; Zehetner, F.; Rampazzo, N.; Wimmer, B.; Soja, G. Long-term effects of biochar on soil physical properties. Geoderma 2016, 282, 96-102. [CrossRef]

17. Gul, S.; Whalen, J.K. Biochemical cycling of nitrogen and phosphorus in biochar-amended soils. Soil Biol. Biochem. 2016, 103, 1-15. [CrossRef]

18. Yu, L.; Yu, M.; Lu, X.; Tang, C.; Liu, X.; Brookes, P.; Xu, J. Combined application of biochar and nitrogen fertilizer benefits nitrogen retention in the rhizosphere of soybean by increasing microbial biomass but not altering microbial community structure. Sci. Total Environ. 2018, 640, 1221-1230. [CrossRef]

19. Liu, Y.; Lonappan, L.; Brar, S.K.; Yang, S.M. Impact of biochar amendment in agricultural soils on the sorption, desorption, and degradation of pesticides: A review. Sci. Total Environ. 2018, 645, 60-70. [CrossRef]

20. Liu, Q.; Zhang, Y.; Liu, B.; Amonette, J.E.; Lin, Z.; Liu, G.; Ambus, P.; Xie, Z. How does biochar influence soil N cycle? A meta-analysis. Plant Soil 2018, 426, 211-225. [CrossRef]

21. Zwieten, L.V.; Rose, T.; Herridge, D.; Kimber, S.; Rust, J.; Cowie, A.; Morris, S. Enhanced biological N2 fixation and yield of faba bean (Vicia faba L.) in an acid soil following biochar addition: Dissection of causal mechanisms. Plant Soil 2015, 395, 7-20. [CrossRef]

22. Scheifele, M.; Hobi, A.; Buegger, F.; Gattinger, A.; Schulin, R.; Boller, T.; Mäder, P. Impact of pyrochar and hydrochar on soybean (Glycine max L.) root nodulation and biological nitrogen fixation. J. Plant Nutr. Soil Sci. 2017, 180, 199-211. [CrossRef]

23. Ahmad, M.; Upamali, A.R.; Lim, J.E.; Zhang, M.; Bolan, N.; Mohan, D.; Vithanage, M.; Lee, S.S.; OK, S.Y. Biochar as a sorbent for contaminant management in soil and water: A review. Chemosphere 2014, 99, 19-33. [CrossRef]

24. Lehmanna, J.; Rillig, M.C.; Thies, J.; Masiello, C.A.; Hockadayd, W.C.; Crowley, D. Biochar effects on soil biota-A review. Soil Biol. Biochem. 2011, 43, 1812-1836. [CrossRef]

25. Zhu, X.; Chen, B.; Zhu, L.; Xing, B. Effects and mechanisms of biochar-microbe interactions in soil improvement and pollution remediation: A review. Environ. Pollut. 2017, 227, 98-115. [CrossRef]

26. Pietikäinen, J.; Kiikkilä, O.; Fritze, H. Charcoal as a habitat for microbes and its effect on the microbial community of the underlying humus. Oikos 2000, 89, 231-242. [CrossRef] 
27. Li, Q.; Liang, J.; Zhang, X.; Feng, J.; Song, M.; Gao, J. Biochar addition affects root morphology and nitrogen uptake capacity in common reed (Phragmites australis). Sci. Total Environ. 2021, 766, 144381. [CrossRef] [PubMed]

28. Zhou, J.; Yin, T.; Qian, C.; Liao, Z.; Shu, Y.; Li, S. Seed coat morphology in Sapium sebiferum in relation to its mechanism of water uptake. J. Hortic. Sci. Biotechnol. 2015, 90, 613-618. [CrossRef]

29. Blouin, M.; Barot, S.; Roumet, C. A quick method to determine root biomass distribution in diameter classes. Plant Soil 2007, 290, 371-381. [CrossRef]

30. Judd, L.A.; Jackson, B.E.; Fonteno, W.C. Advancements in root growth measurement technologies and observation capabilities for container-grown plants. Plants 2015, 4, 369-392. [CrossRef]

31. Greenan, N.S.; Mulvaney, R.L.; Sims, G.K. A microscale method for colorimetric determination of urea in soil extracts. Commun. Soil Sci. Plant Anal. 1995, 26, 2519-2529. [CrossRef]

32. Stitt, M.; Müller, C.; Matt, P.; Gibon, Y.; Carillo, P.; Morcuende, R.; Scheible, R.; Krapp, A. Steps towards an integrated view of nitrogen metabolism. J. Exp. Bot. 2002, 53, 959-970. [CrossRef]

33. Jaworski, E.G. Nitrate reductase assay in intact plant tissues. Biochem. Biophys. Res. Commun. 1971, 43, 1274-1279. [CrossRef]

34. Sorrenti, G.; Ventura, M.; Toselli, M. Effect of biochar on nutrient retention and nectarine tree performance: A three-year field trial. J. Plant Nutr. Soil Sci. 2016, 179, 336-346. [CrossRef]

35. Lu, K.; Yang, X.; Gielen, G.; Bolan, N.; Ok, Y.S.; Niazi, N.K.; Xu, S.; Yuan, G.; Chen, X.; Zhang, X.; et al. Effect of bamboo and rice straw biochars on the mobility and redistribution of heavy metals $(\mathrm{Cd}, \mathrm{Cu}, \mathrm{Pb}$ and $\mathrm{Zn})$ in contaminated soil. J. Environ. Manag. 2017, 186, 285-292. [CrossRef]

36. Xiang, Y.; Deng, Q.; Duan, H.; Guo, Y. Effects of biochar application on root traits: A meta-analysis. Glob. Chang. Biol. 2017, 9, 1563-1572. [CrossRef]

37. Backer, R.G.M.; Saeed, W.; Seguin, P.; Smith, L.D. Root traits and nitrogen fertilizer recovery efficiency of corn grown in biochar-amended soil under greenhouse conditions. Plant Soil 2017, 415, 465-477. [CrossRef]

38. Lu, K.; Yang, X.; Shen, J.; Robinson, B.; Huang, H.; Liu, D.; Bolan, N.; Pei, J.; Wang, H. Effect of bamboo and rice straw biochars on the bioavailability of $\mathrm{Cd}, \mathrm{Cu}, \mathrm{Pb}$ and $\mathrm{Zn}$ to Sedum plumbizincicola. Agric. Ecosyst. Environ. 2014, 191, 124-132. [CrossRef]

39. Oguntunde, P.G.; Abiodun, B.J.; Ajayi, A.E.; van de Giesen, N. Effects of charcoal production on soil physical properties in Ghana. J. Soil Sci. Plant Nutr. 2008, 182, 863-998. [CrossRef]

40. Brockhoff, S.R.; Christians, N.E.; Killorn, R.J.; Horton, R.; Davis, D.D. Physical and mineral-nutrition properties of sand-based turfgrass root zones amended with biochar. Agron. J. 2010, 102, 1627-1631. [CrossRef]

41. Wu, Q.; Pagès, L.; Wu, J. Relationships between root diameter, root length and root branching along lateral roots in adult, field-grown maize. Ann. Bot. 2016, 117, 379-390. [CrossRef]

42. Lehmann, J.; da Silva, J.P.J.; Steiner, C.; Nehls, T.; Zech, W.; Glaser, B. Nutrient availability and leaching in an archaeological anthrosol and a ferrasol of the Central Amazon basin: Fertilizer, manure, and charcoal amendments. Plant Soil 2003, 249, 343-357. [CrossRef]

43. Chen, S.; Rotaru, A.; Shrestha, P.M.; Malvankar, N.S.; Liu, F.; Fan, W.; Nevin, K.P.; Lovely, D.R. Promoting interspecies electron transfer with biochar. Nature 2014, 4, 5019. [CrossRef]

44. Lehmann, J.; Skjemstad, J.; Sohi, S.; Carter, J.; Barson, M.; Falloon, P.; Coleman, K.; Woodbury, P.; Krull, E. Australian climatecarbon cycle feedback reduced by soil black carbon. Nat. Geosci. 2008, 1, 832-835. [CrossRef]

45. Van Zwieten, L.; Kimber, S.; Morris, S.; Chan, K.Y.; Downie, A.; Rust, J.; Joseph, S.; Cowie, A. Effects of biochar from slow pyrolysis of papermill waste on agronomic performance and soil fertility. Plant Soil 2010, 327, 235-246. [CrossRef]

46. Ajema, L. Effects of biochar application on beneficial soil organism review. Int. J. Res. Stud. Sci. Eng. Tech. 2018, 5, 9-18. [CrossRef]

47. Rawat, J.; Saxena, J.; Sanwal, P. Biochar: A sustainable approach for improving plant growth and soil properties. In Biochar-An Imperative Amendment for Soil and the Environment; Vikas Abrol and Peeyush Sharma; IntechOpen: New York, NY, USA, 2019. [CrossRef]

48. Crawford, M.N. Nitrate: Nutrient and signal for plant growth. Plant Cell 1995, 7, 859-868. [CrossRef] [PubMed]

49. Hagemann, N.; Kammann, C.I.; Schmidt, H.P.; Kappler, A.; Behrens, S. Nitrate capture and slow release in biochar amended compost and soil. PLoS ONE 2017, 12, e0171214. [CrossRef]

50. Wardle, D.A.; Nilsson, M.C.; Zackrisson, O. Fire-derived charcoal causes loss of forest humus. Science 2008, 320, 629. [CrossRef]

51. Laird, D.; Fleming, P.; Wang, B.; Horton, R.; Karlen, D. Biochar impact on nutrient leaching from a Midwestern agricultural soil. Geoderma 2010, 158, 436-442. [CrossRef]

52. Nielsen, S.; Minchin, T.; Kimber, S.; van Zwieten, L.; Gilbert, J.; Munroe, P.; Joseph, S.; Thomas, T. Comparative analysis of the microbial communities in agricultural soil amended with enhanced biochars or traditional fertilisers. Agric. Ecosyst. Environ. 2014, 191, 73-82. [CrossRef]

53. Harel, Y.M.; Elad, Y.; Rav-David, D.; Borenstein, M.; Shulchani, R.; Lew, B.; Graber, E.R. Biochar mediates systemic response of strawberry to foliar fungal pathogens. Plant Soil 2012, 357, 245-257. [CrossRef]

54. Chen, X.; Lewis, S.; Heal, K.V.; Lin, Q.; Sohi, S.P. Biochar engineering and ageing influence the spatiotemporal dynamics of soil $\mathrm{pH}$ in the charosphere. Geoderma 2021, 386, 114919. [CrossRef]

55. Yu, M.; Meng, J.; Yu, L.; Su, W.; Afzal, M.; Li, Y.; Brookes, P.C.; Redmile-Gordon, M.; Luo, Y.; Xu, J. Changes in nitrogen related functional genes along soil pH, C and nutrient gradients in the charosphere. Sci. Total Environ. 2019, 650, 626-632. [CrossRef] [PubMed] 